\title{
The role of biosimilars in value-based oncology care
}

This article was published in the following Dove Press journal: Cancer Management and Research

\author{
Kashyap B Patel' \\ Luiz H Arantes $\mathrm{Jr}^{2}$ \\ Wing Yu Tang ${ }^{3}$ \\ Selwyn Fung ${ }^{4}$
}

'Carolina Blood and Cancer Care, Rock Hill, SC, USA; ${ }^{2}$ Biosimilars Global Medical Affairs, Pfizer Essential Health, Pfizer Inc. New York, NY, USA; ${ }^{3}$ Health Economics and Outcomes Research, Pfizer Health \& Impact, Pfizer Essential Health, Pfizer Inc. New York, NY, USA; ${ }^{4}$ fizer Essential Health Research \& Development, Pfizer Inc. New York, NY, USA
Correspondence: Selwyn Fung Pfizer Essential Health Research \& Development, Pfizer Inc. 235 East 42 ${ }^{\text {nd }}$ Street, New York, NY 10017, USA $\mathrm{Tel}+\mathrm{I} 3477033165$ Email Selwyn.Fung@Pfizer.com

\begin{abstract}
Biopharmaceuticals (biologics) represent one of the fastest growing sectors of cancer treatment. They are recommended for treating underlying cancer and as supportive care for management of treatment side effects. Given the high costs of cancer care and the need to balance health care provision and associated budgets, patient access and value are the subject of discussion and debate in the USA and globally. As the costs of biologics are high, biosimilars offer the potential of greater choice and value, increased patient access to treatment, and the potential for improved outcomes. Value-based care aims to improve the quality of care, while containing costs. The Centers for Medicare \& Medicaid Services (CMS) has developed valuebased care programs as alternatives to fee-for-service reimbursement, including in oncology, that reward health care providers with incentive payments for improving the quality of care they provide. It is anticipated that CMS payments in oncology care will be increasingly tied to measured performance. This review provides an overview of value-based care models in oncology with a focus on CMS programs and discusses the contribution of biosimilars to CMS value-based care objectives. Biosimilars may provide an important tool for providers participating in value-based care initiatives, resulting in cost savings and efficiencies in the delivery of high-value care through expanded use of biologic treatment and supportive care agents during episodes of cancer care.
\end{abstract}

Keywords: biologics, biosimilars, oncology, patient access, value-based care, supportive care

\section{Introduction}

As of the early 1980s, biopharmaceuticals represent one of the fastest growing sectors of the drug industry worldwide ${ }^{1}$ and are increasingly important in cancer care. Biologics (e.g., monoclonal antibodies [mAbs] and hematopoietic agents) ${ }^{2}$ are recommended in oncology guidelines ${ }^{3}$ for treating underlying disease as well as for managing treatment side effects through supportive care agents such as granulocyte-colony stimulating factors (G-CSFs) and erythropoiesis-stimulating agents (ESAs). ${ }^{4}$

Biologics are produced from cells of living organisms and purified in complex, multi-step processes, including recombinant DNA technology, controlled gene expression, or antibody technologies. ${ }^{2}$ Compared with chemically synthesized small molecule drugs, biologics have 100- to 1000-fold larger molecular weight and are relatively heterogeneous ${ }^{5}$; their physiochemical structure is complex and difficult to characterize. Furthermore, they are highly sensitive to changes in manufacturing conditions, and as a result, no two biological products can be identical, ${ }^{6}$ resulting in a complex production process. Biologic agents, including those used in cancer treatment and 
supportive care, have improved outcomes for patients, who often require ongoing treatment. As costs of biologics are high, long-term treatment of patients with biologics can be a chronic burden to health care systems. ${ }^{7}$

Biosimilars of reference biologic agents offer an alternative choice and value that has potential to open further patient access to treatment and associated outcomes. According to the United States Food and Drug Administration (US FDA) definition, a biosimilar is a biologic product that is highly similar to an already licensed reference biologic that has no clinically meaningful differences in terms of safety, purity, and potency. ${ }^{8,9}$ Biosimilars remain fairly new to the US market, particularly in the oncology space; however, this is anticipated to change rapidly with multiple biosimilar entrants expected in oncological treatment and supportive care in the upcoming years. ${ }^{10}$

Given the disproportionate burden of cancer in the elderly, understanding the intersection of the availability of biosimilars and the growing interest in value-based oncology care models, particularly within the Centers for Medicare \& Medicaid Services (CMS), is of increasing importance in health care delivery.

The objective of this review is to provide an overview of value-based care models in oncology with a focus on the CMS programs and to discuss the potential contribution of biosimilars to CMS value-based care objectives. This review first describes the use of biologics in targeted and supportive oncology care, introduces biosimilars, and then examines the historical legacy and objectives of the CMS value programs with a focus on how biosimilars might support broader access to equitable, high-quality oncology care.

\section{The high cost of cancer care}

The increased prevalence of cancers, earlier treatment initiation, and improved patient outcomes all contribute to the growing use of oncology and supportive care biologic agents. These factors, coupled with the high costs of manufacturing biologics and macro- and micro-economic factors resulting in higher health care costs, have led to a rise in cancer care spending. ${ }^{7,11}$ In high-income countries, the costs of delivering cancer care are outstripping national budgets, and sustainability of health care financing remains a key public policy concern. ${ }^{12}$

\section{Biologics in cancer treatment and supportive care}

Biologics have been approved for use in primary cancer treatment and supportive care since 1989 (Figure 1). Primary treatment biologics include, but are not limited to, cetuximab, ${ }^{13}$ rituximab ${ }^{14}$ (chimeric mAbs targeting epidermal growth factor receptor and CD20, respectively),

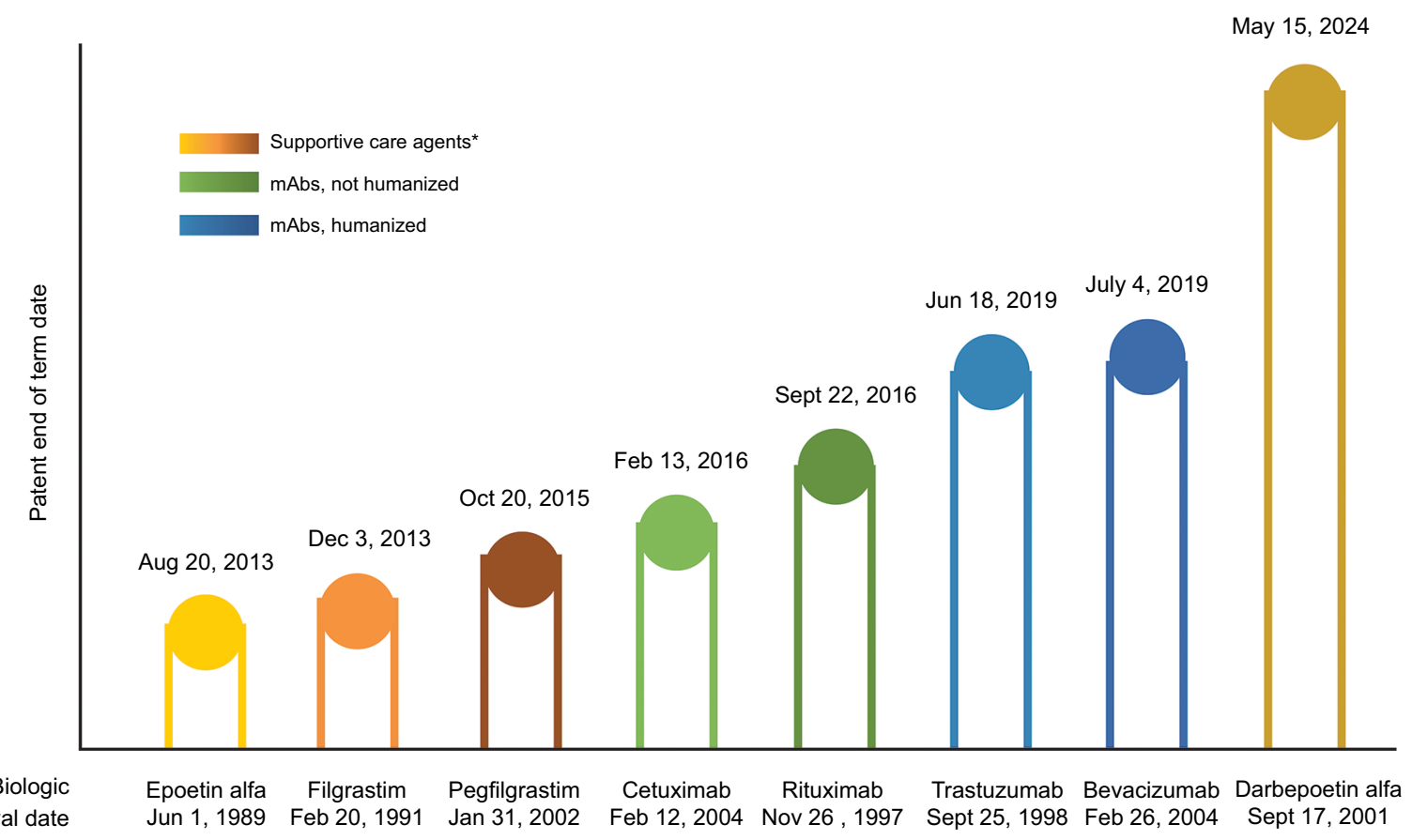

Figure I US patent end of term dates for oncology mAbs and supportive care drugs.

Notes: *Biologic growth factors for the treatment of anemia or neutropenia due to myelosuppressive chemotherapy. Data from Generics and Biosimilars Initiative ${ }^{61}$ and Micklus. ${ }^{103}$

Abbreviation: mAbs, monoclonal antibodies. 
trastuzumab, ${ }^{15}$ and bevacizumab ${ }^{16}$ (humanized mAbs that inhibit human epidermal growth factor receptor 2 and vascular endothelial growth factor A, respectively). These biologics have been shown to improve clinical, health-related quality of life (HRQoL) and hematological outcomes. ${ }^{13,17}$ Biologics are not exclusive to primary treatment, but they have been developed for supportive oncologic treatment as well. Supportive oncologic treatment addresses the adverse effects that are common with primary chemotherapy. Biologics in supportive oncology care include, but are not limited to, agents that help replenish hematologic components during and following chemotherapy. Epoetin alfa and darbepoetin are recombinant human erythropoietic proteins. Filgrastim and its analog, pegfilgrastim, are recombinant human G-CSF. The use of supportive care biologics with chemotherapy improves hematological response $\mathrm{e}^{18-22}$ and has a positive effect on HRQoL. ${ }^{19,20,22,23}$

Biologic therapies have improved treatment outcomes over previous standard-of-care chemotherapy, while biologic supportive care agents have been shown to be associated with reduced treatment side effects resulting in improved patient-reported HRQoL. ${ }^{13,17,22}$ However, patient access to biologics may be limited by availability, insurance coverage, and cost. As many available biologics reach the end of their patent protection periods (US patents for cetuximab expired in 2014, for ritxuimab in 2016, and for both trastuzmumab and bevacizuamb, they will reach the end of term in $2019^{24}$ ), patient access has become an important consideration among the balance of high-quality care and costs. Within the context of this balance, biosimilars are being developed as alternative options with potentially lower costs and greater access. By 2020, a range of biosimilars of biologic agents used in oncology treatment are expected to receive US FDA approval and become available in the US market, providing increased treatment options and thus competition, with the potential for pricing reductions.

\section{Costs of biologics cancer care in the USA}

In the USA, total spending on cancer care has increased from $\$ 27$ billion in 1990 to $\$ 124$ billion in 2010, with spending projected to reach around $\$ 157$ billion by $2020 .^{25,26}$ Total costs of cancer care for the US population are predicted to increase across all phases of care (Figure 2). ${ }^{27}$ Cost drivers include technological innovation, rising costs of hospitalizations, and a population-level increasing susceptibility to malignancy due to an aging demographic and increasing life span. ${ }^{28}$ Global spending on oncology and supportive care drugs reached $\$ 100$ billion in 2014 , with targeted therapy expenditures accounting for almost $50 \%$ of this amount. ${ }^{11}$ In the USA, oncology drug expenditures, excluding supportive care agents, increased by $18.0 \%$ from 2014 to $2015 .{ }^{29}$ The

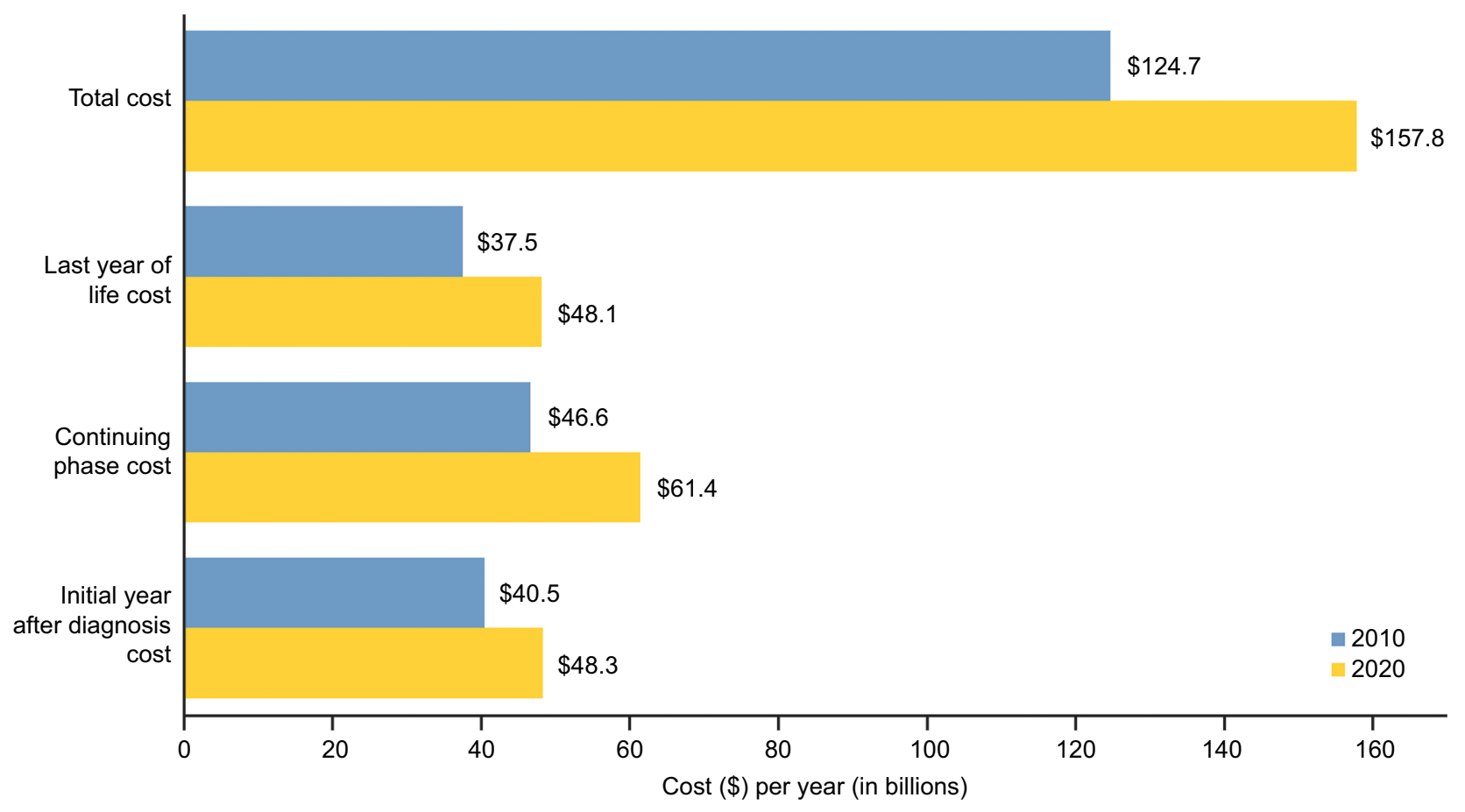

Figure 2 Current and projected cost of cancer care in the USA by phase of care in 2010 and 2020, respectively, weighted to dollar values in 2010. Note: Data from National Cancer Institute. ${ }^{27}$ 
fastest growing drug classes within oncology are mAbs and protein-kinase inhibitors, with mAbs accounting for $35 \%$ of US oncology spending. ${ }^{29}$ US sales figures in 2015 for three of the top 20 global products - bevacizumab, rituximab and trastuzumab - were $\$ 6.2$ billion, $\$ 6.3$ billion, and $\$ 5.6$ billion, respectively. ${ }^{30}$ US patients are shouldering an increasing share of these rising costs as health plans restructure their benefit designs, including a transition to high-deductible health plans with higher patient out-of-pocket costs from traditional fixed copay plans. ${ }^{28}$ The financial consequences of cancer treatment on patients and their families can be substantial, ${ }^{31,32}$ which has been shown to be a substantial burden. ${ }^{33,34}$ Given the high costs of cancer care and the need to balance health care provision and associated budgets for the full range of conditions affecting population health, issues of patient access, value, and equity are the subject of global discussion and debate.

\section{Oncology biosimilars in Europe}

The European Medicines Agency (EMA) first introduced a regulatory framework for biosimilars in 2004, and by 2006 , it had established a comprehensive set of guidelines for their approval. ${ }^{35}$ Since then, European countries have approved the highest number of biosimilars worldwide, having shown high similarity to their reference products via a series of studies (efficacy and safety), and on the basis of nonclinical and pharmaceutical quality data. ${ }^{35,36}$ For example, in the European Union, clinical guidelines were updated in 2009 to encourage the use of biosimilar filgrastim, which led to significantly increased consumption, enabling greater numbers of patients access to this treatment at earlier stages of the therapy cycle. ${ }^{37}$

Approvals for supportive oncology care biosimilars in Europe have been ongoing. As of January 2018, nine filgrastim and five epoetin alfa/zeta biosimilar products were approved $^{38}$ and have had tremendous impact on improving access to treatment. ${ }^{39,40}$ As of this publication, license applications for three pegfilgrastim biosimilars were under review by the EMA. For targeted therapies, five rituximab biosimilars, all licensed for the same or similar oncology indications, ${ }^{38}$ are authorized by the EMA, and five trastuzumab biosimilars are still under review. ${ }^{41}$

Biosimilars provide an opportunity for cost savings. In Europe, individual member states are allowed to negotiate their own pricing on biosimilars. ${ }^{24,42}$ According to a 2016 IMS report, ${ }^{37}$ the observed price reduction for epoetins (in 2015) following the introduction of biosimilar competition varied substantially among countries: $25 \%-29 \%$ in Scandinavia; 39\% in France; and 55\% in Germany. Meanwhile, the observed price change (in 2015) for biologic and biosimilar filgrastim, following the launch of the first approved filgrastim biosimilar, varied from $14 \%$ in France to $27 \%$ in Germany, based on gross ex-manufacturer price. ${ }^{37} \mathrm{~A}$ significant increase in consumption of therapeutic biologics and biosimilars has been shown in European countries upon entry of a biosimilar into the market ${ }^{43}$ and this increase is attributed to reduced costs. ${ }^{44,45}$ It should be noted, however, that owing to substantial international differences in market forces, drug pricing, and health care policy (as well as in access and utilization), European pricing data are not applicable to the US market. ${ }^{46}$

\section{Biosimilar use in other regions}

Biosimilars are used widely in the Middle East ${ }^{47}$ and in Asia. ${ }^{48}$ Reasons for use include lower price relative to reference biologics and bioequivalence of efficacy and safety. ${ }^{47}$ Regulatory approvals, where needed, are largely modeled after US FDA and EMA guidelines. ${ }^{48}$

\section{Biosimilars in cancer treatment and supportive care in the USA}

The USA has a regulatory framework for biosimilars, which was enacted as the 2009 Biologics Price Competition and Innovation (BPCI) Act, ${ }^{49}$ part of the Patient Protection and Affordable Care Act. This created an abbreviated licensure pathway for biological products demonstrated to be biosimilar to, or interchangeable with, a US FDA-licensed biological product (or "reference product"), known as the 351(k) pathway. ${ }^{8}$ The Congressional Budget Office estimates that the sales-weighted market average discount on biosimilars would be $20 \%-25 \%$ relative to reference agents. ${ }^{50}$ The regulatory framework and evidence requirements of the US biosimilars program involve a stepwise approach that relies heavily on analytical methods to demonstrate, through the "totality of evidence" (i.e., all available analytical, nonclinical, and clinical data), that a proposed biosimilar functions the same way as its reference product. ${ }^{51,52}$

Biosimilars have been available globally since 2008, with the first US biosimilar, the G-CSF filgrastim-sndz, available in the USA since September $2016 .{ }^{53,54}$ Wholesale acquisition costs (WACs) in the USA for 2017 show a 15\% discount for biosimilar filgrastim-sndz over filgrastim; a recent cost-efficiency analysis determined that prophylaxis with filgrastimsndz was associated with consistently significant cost savings over filgrastim and pegfilgrastim. ${ }^{55,56}$ The alternate filgrastim agent, tbo-filgrastim (which is not a biosimilar in the USA and is approved for only one filgrastim indication), is available at a $23 \%$ discount compared to the WAC for filgrastim 
(Figure 3A). ${ }^{57}$ Based on CMS payment limits (i.e., average sales price plus $6 \%$ ) for fourth quarter of 2017 , the payment limit for biosimilar filgrastim-sndz was $28 \%$ lower than for filgrastim, while for alternate agent tbo-filgrastim, pricing was $36 \%$ lower than for filgrastim (Figure 3B). ${ }^{58}$ Thus, the filgrastim biosimilar and alternate agent provide cost savings under the pricing available to commercial payers and CMS payment limits.

Multiple biosimilars are expected to obtain US FDA approval and enter the US market in the next 2-3 years as patent protection of reference supportive care drugs have come to the end of term recently or are expiring soon (Figure 1). ${ }^{59-61}$ As of this writing, filgrastim-sndz is the only approved biosimilar for supportive oncology care under the US FDA BPCI, but in May 2017, the US FDA Oncologic
Drugs Advisory Committee recommended approval of an epoetin alfa biosimilar across all licensed indications of the reference product. ${ }^{62,63}$ Also regarding biosimilar supportive care, Biologics License applications for four proposed biosimilars of G-CSF pegfilgrastim have been under review by the US FDA as of June 2017 $64-66$; however, two of these applications were rejected and two others were still pending as of this writing. Biosimilars of targeted therapies bevacizumab (September 2017) and trastuzumab (December 2017) have recently been approved by the US FDA. Also in 2017, the US FDA has accepted a new Biologics License Application for a filgrastim biosimilar (September) ${ }^{67}$ as well as biosimilars of rituximab ${ }^{68}$ and trastuzumab. ${ }^{68-70}$ As more biosimilars become available after receiving regulatory approval, adoption in clinical practice is expected to increase. Biosimilar

A

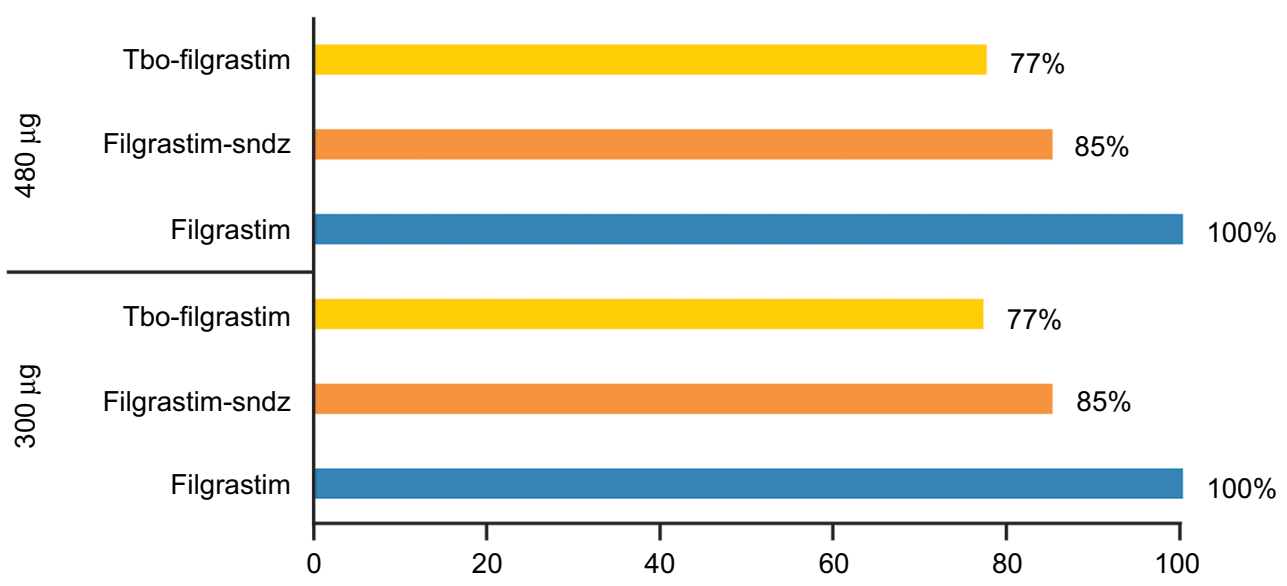

Filgrastim WAC price (\%)

B

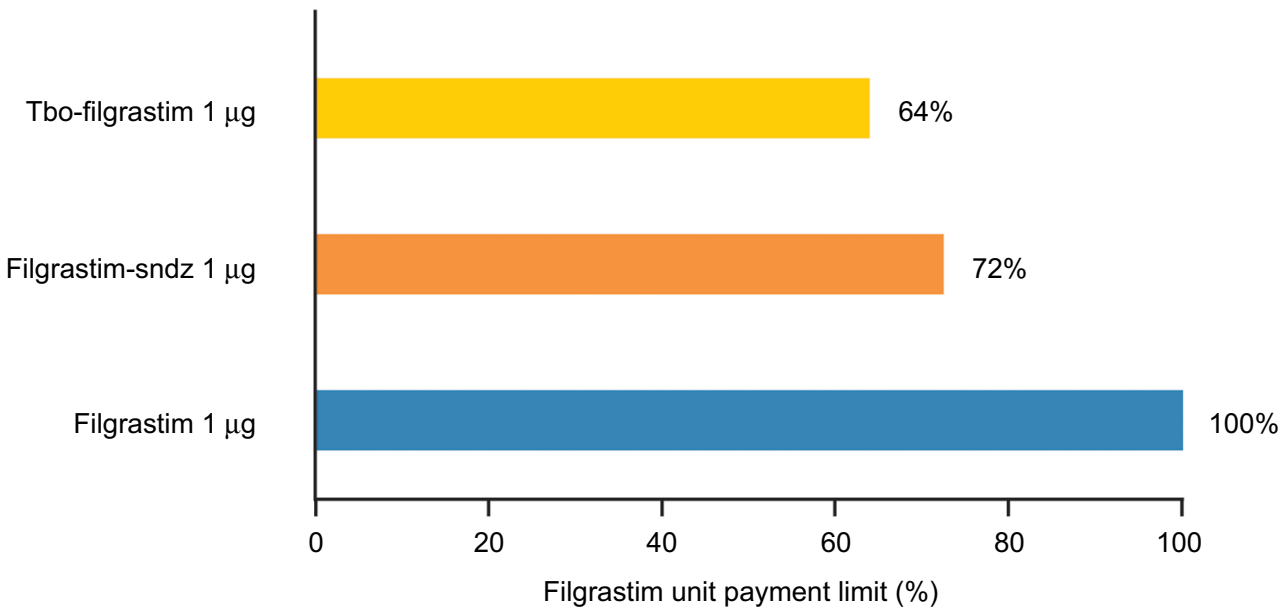

Figure 3 Commercial price comparison for short-acting G-CSFs (filgrastim-sndz, tbo-filgrastim, and filgrastim) based on the fourth quarter of 2017 (A) WAC/average wholesale price in the USA ${ }^{57}$ and (B) CMS payment limits (average sales price $+6 \%$ ). ${ }^{58}$

Abbreviations: AWP, average wholesale price; $\mu$ g, microgram; CMS, Centers for Medicare \& Medicaid Services; G-CSFs, granulocyte-colony stimulating factors; WAC, wholesale acquisition cost. 
therapies are expected to improve access and to reduce overall pharmaceutical expenditures.

\section{Value-based oncology frameworks}

With ongoing concerns about the escalating costs of cancer care, a number of US professional and private organizations have developed value assessment frameworks to define and measure the value of oncology drugs and other therapies. ${ }^{28,71-75}$ The overarching objectives of these frameworks differ, with some tailored to support physicians and patients in making informed, evidence-based treatment decisions, and others designed as tools to assist in coverage or reimbursement decisions. To date, however, these frameworks provide suggested guidance only; none has been implemented in US clinical practice or in a payer environment.

Outside of the USA, the UK's National Institute for Health and Care Excellence (NICE) and decision-making bodies in and many other countries use a health technology assessment (HTA) approach, which includes cost-effectiveness models and incremental cost-effectiveness ratios, for health care reimbursement decision making. While it could be argued that countries using HTAs include some measure of valuebased care, it should be noted that the National Health Service in England has studied incentive programs and value-based payments as a means to address inequalities in health care, but comprehensive programs have not been implemented as of this writing. ${ }^{76}$

\section{The CMS value-based care programs}

The CMS has developed value-based care programs that reward health care providers with incentive payments for improving the quality of care they provide to Medicare beneficiaries. In the future, it is anticipated that CMS payments will be increasingly tied to measured performance in oncology care. ${ }^{77}$

\section{The CMS Quality Payment Program (QPP)}

Fee-for-service (FFS) is a common US payment model in which medical services are not bundled, but paid for individually, thus incentivizing provision of high-quantity (but not necessarily high-quality) health care. An underlying tenant of value-based care is to move away from the FFS model and toward performance-based payments. In October 2016, the CMS finalized the Medicare Access and CHIP Reauthorization Act of $2015^{78}$ that implemented the QPP (Figure 4). The QPP began in January 2017, with payment adjustments based on performance to be fully implemented by January $2019 .{ }^{79}$ The QPP offers payment according to one of two tracks: 1) a Merit-based Incentive Payment System linked to performance including following defined, evidence-based clinical quality measures, and 2) Advanced Alternative Payment Models (APMs) ${ }^{80}$ that give financial incentives to clinicians to provide high-quality and costefficient care (Figure 5). ${ }^{78,81,82}$ One of the Advanced APMs is the Oncology Care Model (OCM). ${ }^{81,83}$

\section{The CMS OCM}

In response to rising cancer treatment costs, in June 2016, the CMS launched a new, voluntary $\mathrm{OCM}^{84,85}$ as part of its broader initiative to improve the effectiveness and efficiency of specialty care; the program aims to provide higher quality, more coordinated oncology care at the same or lower cost to Medicare than traditional FFS payments (Figure 4A and B). ${ }^{86}$ The OCM program ties payments to provider performance based on meeting specified quality metrics and practice reforms, with some practices already entering into payment arrangements that include financial and performance accountability for episodes of care involving chemotherapy administration to patients with cancer. As of this writing, the program is scheduled for 2017 through 2022. In July 2017, 192 practices and 14 commercial payers were participating in the OCM. ${ }^{84}$

The OCM incorporates a two-part payment system for physician practices: a per-beneficiary Monthly Enhanced Oncology Services (MEOS) payment and a performance-based incentive payment (Figure 5). The MEOS payment assists participating practices in effectively managing and coordinating episodes of care for oncology patients. The performance-based incentive payment is calculated retrospectively on a semiannual basis, based on the practice's achievements in quality measures and reductions in Medicare expenditures.

\section{The role of biosimilars in value- based oncology care programs}

The Advanced APM track of the QPP is designed to give Medicare providers greater flexibility in delivering valuebased care tailored to the type of care they provide. As specific examples of Advanced APMs, the Medicare Shared Savings Program (MSSP) two-sided risk models and OCM were developed to deliver more effective and efficient specialty care through the provision of higher-quality, more coordinated care at the same or lower cost to Medicare as the traditional FFS model, utilizing participant-reported quality metric data to measure and reward high-value oncology care. Participants in the OCM and other similar incentives have an opportunity to play a key role in identifying clinical care practices to meet CMS program assessment goals including patient experience, reduced shared cost, and improved patient outcomes. 
A

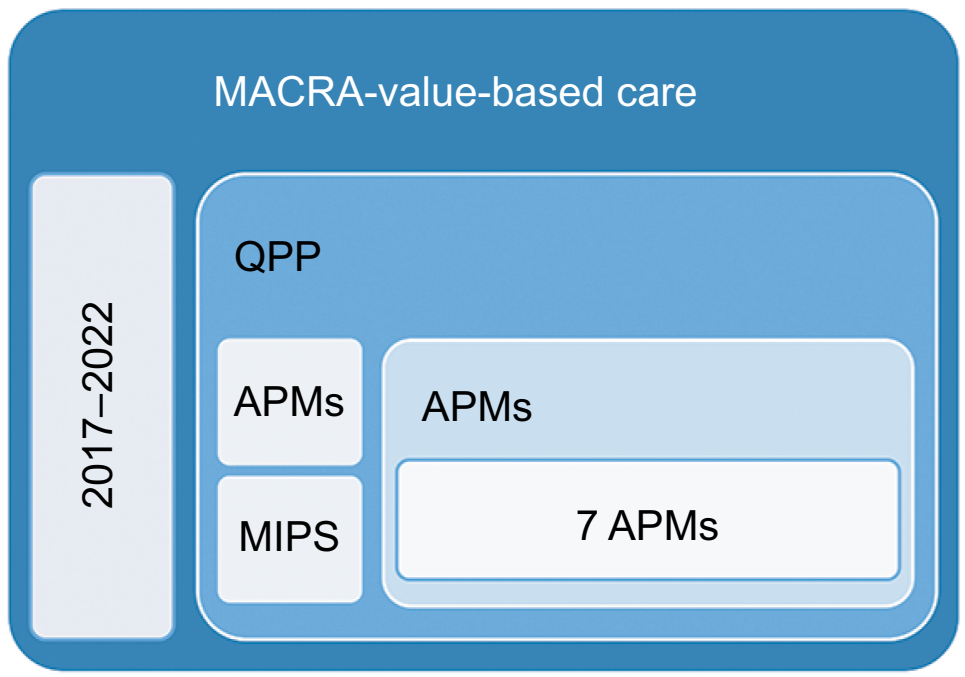

B

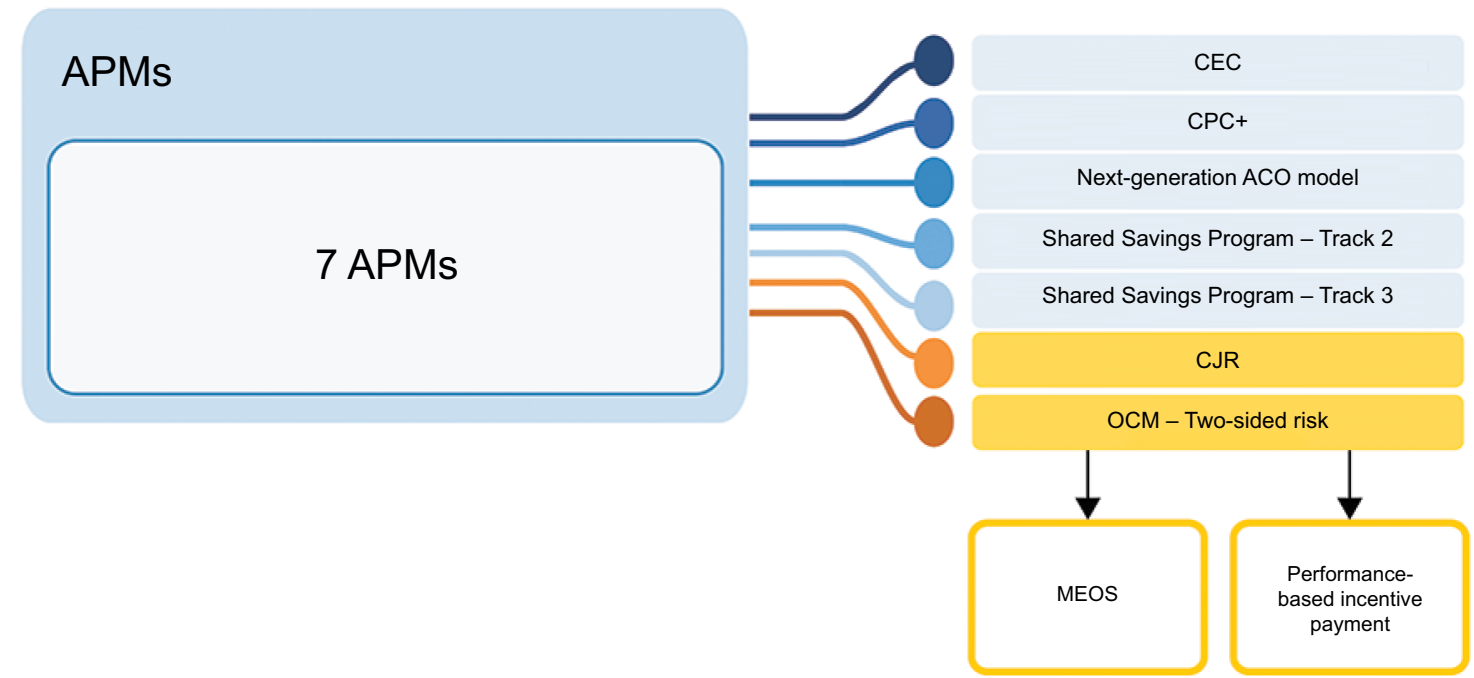

Figure 4 OCM key drivers of cost reduction.

Notes: Data from Quality Payment Program, Centers for Medicare and Medicaid Services. ${ }^{86}$ (A) Overview of payment programs under MACRA. (B) Overview of the Advanced Payment Models, including details on the OCM.

Abbreviations: APM, Alternative Payment Model; ACO, Accountable Care Organization; CEC, Comprehensive ESRD Care; CJR, Comprehensive Care for Joint Replacement; CPC+, Comprehensive Primary Care Plus; MACRA, Medicare Access and CHiP Reauthorization Act of 20I5; MEOS, Monthly Enhanced Oncology Services; MIPS, Merit-based Incentive Payment System; OCM, Oncology Care Model; QPP, Quality Payment Program.

Biosimilars offer potential benefits under the OCM, including enhanced affordability and increased access to biologic treatments, along with the improved outcomes and HRQoL associated with biologics in both cancer treatment and supportive care. For example, the use of G-CSF as supportive care in 1,655 patients receiving standard-of-care chemotherapy for breast cancer reduced the incidence of neutropenia, which led to increased dose administration of the primary treatment and improved survival outcomes. ${ }^{87}$ Availability of biosimilars in the oncology setting in the European Union has expanded patient access to treatment that previously may have been unavailable due to cost. ${ }^{39}$
Economic modeling studies from Germany, France, Italy, Spain, and the United Kingdom have shown cost savings along with expanded access to supportive care treatments including biosimilar filgrastim ${ }^{88,89}$ and biosimilar epoetin alfa, ${ }^{90}$ compared with their respective reference biologics. This is illustrated by a budget impact analysis of real-world data for biosimilar rituximab (for rheumatology and cancer) in 28 European countries ${ }^{11}$ and by a recent Croatian study evaluating the budget impact of biosimilar trastuzumab for the treatment of breast cancer. ${ }^{92}$ These European examples provide insight into possible cost-savings scenarios with biosimilars in the USA; however, due to the unique nature 


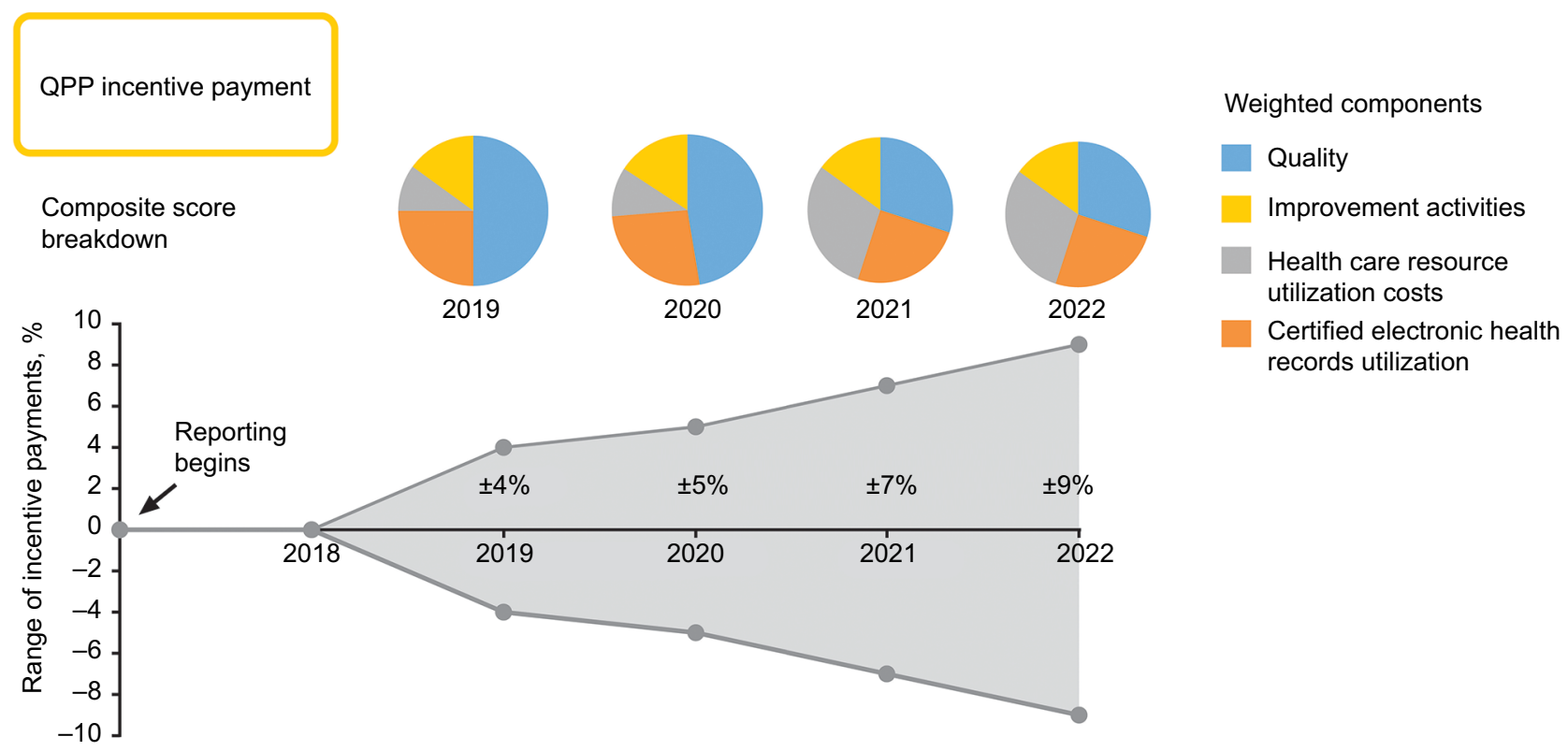

Figure 5 Range and weighted components of payments in the incentive payment program under the QPP. Note: 2022 weighted components assumed, based on 2021 requirements.

Abbreviation: QPP, quality payment program.

of the US health care market, it is unknown whether cost savings from biosimilars observed in Europe and elsewhere will manifest in the USA once a greater range of biosimilars used in cancer care are approved and available for use.

Biosimilars may offer a more affordable alternative to biologics as well as result in overall price decreases from market competition, which could result in substantial costsavings in the USA..$^{37,93-97}$ These benefits have been demonstrated for biosimilar filgrastim, for which CMS (ASP $+6 \%$ ) pricing shows a $28 \%$ discount over the reference biologic. The Rand Corporation reports that savings to the US health care system incurred from the use of biosimilars over biologics range from an estimated $\$ 13$ billion to $\$ 66$ billion over the 10-year period between 2014 and 2024. ${ }^{98}$ It is anticipated that the expanded treatment choices provided by biosimilars will open up new opportunities to improve value and care delivery. With biosimilar filgrastim available in the USA and biosimilar epoetin alfa expected to be available soon, the potential for clinicians to utilize these two supportive care biosimilars in oncology care, along with biosimilar targeted therapies, could be an important component in meeting MSSP and OCM objectives to improve the quality of care while reducing costs.

Realization of cost savings possible from biosimilars, however, will require that biosimilars are utilized. ${ }^{99}$ Results of a 2015-2016 survey led by the Biosimilars Forum ${ }^{100}$ showed that major knowledge gaps about biosimilars and their potential use in clinical practice still exist among US specialty physicians, including oncologists. Key gaps include defining biologics versus biosimilars in the context of biosimilarity, understanding the approval process and the use of the "totality of evidence" approach by the US FDA for biosimilar evaluation, understanding the evidence requirements for demonstration of safety and immunogenicity of a biosimilar versus its reference product, understanding the rationale for indication extrapolation, and defining interchangeability in the context of pharmacy-level substitution.

US physicians are now becoming more receptive to prescribing biosimilars, as a potentially important way to reduce drug costs and open access to effective therapies. ${ }^{101,102}$ A recent survey showed that efficacy $(89 \%)$, safety $(81 \%)$, and patient costs $(71 \%)$ were the most important factors in determining whether US physicians would prescribe biosimilars overall, with discounts being a key influencer in anticipated prescribing patterns. ${ }^{102}$ As additional biosimilars are approved in the USA and awareness grows, it is anticipated that biosimilar uptake and utilization will increase. There is a need to educate US physicians about biosimilars and to raise awareness among US payers and patients as well as health care providers in order to increase utilization of these potentially cost-saving therapies.

\section{Conclusion}

The goal of value-based care in oncology is to improve the quality of care, while containing costs. Advanced APMs such as the MSSP two-sided risk models and OCM are examples of 
a shift away from the traditional volume-based FFS model. For the OCM, this objective targets Medicare beneficiaries through an episode-based payment model that financially incentivizes high-quality, coordinated care. In moving toward a value-based specialized care system, payers recognize and reward providers who proactively seek to improve the patient experience and health outcomes. Biosimilars may provide an additional tool for providers participating in value-based care initiatives such as the MSSP and OCM, resulting in cost savings and efficiencies in the delivery of high-value care through expanded use of biologic treatment and supportive care agents during episodes of care. These savings may then be realized through the MSSP, OCM, or other incentive programs, with benefits passed on to health care providers, payers, and patients alike.

\section{Acknowledgments}

Medical writing support was provided by Robyn Fowler, $\mathrm{PhD}$, Patricia McChesney, PhD, CMPP, and Karen Smoyer, $\mathrm{PhD}$, of Engage Scientific Solutions and funded by Pfizer Inc. Financial support for this review was sponsored by Pfizer Inc.

\section{Disclosure}

Dr Patel has been a consultant to Pfizer Inc at advisory boards. Dr Arantes Jr, Ms Tang, and Dr Fung are employees and stockholders of Pfizer Inc. The authors report no other conflicts of interest in this work.

\section{References}

1. Frank RG. Regulation of follow-on biologics. NEnglJMed. 2007;357(9): 841-843.

2. Pasina L, Casadei G, Nobili A. Biological agents and biosimilars: essential information for the internist. Eur J Intern Med. 2016;33:28-35.

3. Zelenetz AD, Ahmed I, Braud EL, et al. NCCN biosimilars white paper: regulatory, scientific, and patient safety perspectives. $J$ Natl Compr Canc Netw. 2011;9(Suppl 4):S1-S22.

4. Hus I. Follow-on biologics in oncology - the need for global and local regulations. Contemp Oncol (Pozn). 2012;16(6):461-466.

5. Kuhlmann M, Covic A. The protein science of biosimilars. Nephrol Dial Transplant. 2006;21(Suppl 5):v4-v8.

6. Morrow T, Felcone LH. Defining the difference: what makes biologics unique. Biotechnol Healthc. 2004;1(4):24-29.

7. Buske C, Ogura M, Kwon HC, Yoon SW. An introduction to biosimilar cancer therapeutics: definitions, rationale for development and regulatory requirements. Future Oncol. 2017;13(15s):5-16.

8. U.S. Food \& Drug Administration [webpage on the Internet]. Information on Biosimilars. 2016; https://www.fda.gov/Drugs/DevelopmentApprovalProcess/HowDrugsareDevelopedandApproved/ ApprovalApplications/TherapeuticBiologicApplications/Biosimilars/. Accessed May 18, 2017.

9. U.S. Food and Drug Administration. Scientific considerations in demonstrating biosimilarity to a reference product: guidance for industry. 2015; http://www.fda.gov/downloads/DrugsGuidanceComplianceRegulatoryInformation/Guidances/UCM291128.pdf. Accessed May 18, 2017.

10. Camacho LH. Current status of biosimilars in oncology. Drugs. 2017;77(9):985-997.
11. IMS Health. Developments in cancer treatments, market dynamics, patient access and value. Global oncology trend report 2015. 2015; http://keionline.org/sites/default/files/IIHI_Oncology_Trend_ Report_2015.pdf. Accessed May 17, 2017.

12. Sullivan R, Peppercorn J, Sikora K, et al. Delivering affordable cancer care in high-income countries. Lancet Oncol. 2011;12(10):933-980.

13. Chan DLH, Segelov E, Wong RS, et al. Epidermal growth factor receptor (EGFR) inhibitors for metastatic colorectal cancer. Cochrane Database Syst Rev. 2017;6:CD007047.

14. Porter DL, Levine BL, Kalos M, Bagg A, June CH. Chimeric antigen receptor-modified T cells in chronic lymphoid leukemia. $N$ Engl $J$ Med. 2011;365(8):725-733.

15. Bang YJ, Van Cutsem E, Feyereislova A; ToGA Trial Investigators. Trastuzumab in combination with chemotherapy versus chemotherapy alone for treatment of HER2-positive advanced gastric or gastro-oesophageal junction cancer (ToGA): a phase 3, open-label, randomised controlled trial. Lancet. 2010;376(9742):687-697.

16. Saltz LB, Clarke S, Diaz-Rubio E, et al. Bevacizumab in combination with oxaliplatin-based chemotherapy as first-line therapy in metastatic colorectal cancer: a randomized phase III study. J Clin Oncol. 2008;26(12):2013-2019.

17. Argiris A, Harrington KJ, Tahara M, et al. Evidence-based treatment options in recurrent and/or metastatic squamous cell carcinoma of the head and neck. Front Oncol. 2017;7:72.

18. Vansteenkiste J, Pirker R, Massuti B, et al. Double-blind, placebo-controlled, randomized phase III trial of darbepoetin alfa in lung cancer patients receiving chemotherapy. J Natl Cancer Inst. 2002;94(16):1211-1220.

19. Dammacco F, Castoldi G, Rodjer S. Efficacy of epoetin alfa in the treatment of anaemia of multiple myeloma. Br J Haematol. 2001;113(1):172-179.

20. Iconomou G, Koutras A, Rigopoulos A, Vagenakis AG, Kalofonos HP. Effect of recombinant human erythropoietin on quality of life in cancer patients receiving chemotherapy: results of a randomized, controlled trial. J Pain Symptom Manage. 2003;25(6):512-518.

21. Osterborg A, Boogaerts MA, Cimino R, et al. Recombinant human erythropoietin in transfusion-dependent anemic patients with multiple myeloma and non-Hodgkin's lymphoma - a randomized multicenter study. The European Study Group of Erythropoietin (Epoetin Beta) Treatment in Multiple Myeloma and Non-Hodgkin's Lymphoma. Blood. 1996;87(7):2675-2682.

22. Wilson J, Yao GL, Raftery J, et al. A systematic review and economic evaluation of epoetin alpha, epoetin beta and darbepoetin alpha in anaemia associated with cancer, especially that attributable to cancer treatment. Health Technol Assess. 2007;11(13):1-202, iii-iv.

23. Coiffier B, Boogaerts M, Kaine C, editors. Impact of Epoetin Beta Versus Standard Care on Quality of Life in Patients with Malignant Disease. 6th Congress of the European Haematology Association, Frankfurt, Germany, June 2001. Abstract no. 194.

24. INC Research. The State of Biosimilars, A FirstWord Perspectives Report. Available from: http://www.firstwordplus.com/images/ads/ TheStateofBiosimilars.pdf. Accessed May 18, 2017.

25. Elkin EB, Bach PB. Cancer's next frontier: addressing high and increasing costs. JAMA. 2010;303(11):1086-1087.

26. Mariotto AB, Yabroff KR, Shao Y, Feuer EJ, Brown ML. Projections of the cost of cancer care in the United States: 2010-2020. J Natl Cancer Inst. 2011;103(2):117-128.

27. National Cancer Institute [webpage on the Internet]. Cancer prevalence and cost of care projections. 2017; https://costprojections.cancer.gov/. Accessed June 26, 2017.

28. Schnipper LE, Davidson NE, Wollins DS, et al. American Society of Clinical Oncology statement: a conceptual framework to assess the value of cancer treatment options. J Clin Oncol. 2015;33(23):2563-2577.

29. IMS Health. Medicines use and spending in the US. A review of 2015 and outlook to 2020. 2016; https://morningconsult.com/wpcontent/uploads/2016/04/IMS-Institute-US-Drug-Spending-2015.pdf. Accessed May 17, 2017. 
30. IMS Health. Top 20 global products 2015. 2015; http://www.imshealth. $\mathrm{com} /$ files/web/Corporate/News/Top-Line\%20Market\%20Data/ Top_20_Global_Products_2015.pdf. Accessed May 17, 2017.

31. de Souza JA, Yap BJ, Wroblewski K, et al. Measuring financial toxicity as a clinically relevant patient-reported outcome: the validation of the COmprehensive Score for financial Toxicity (COST). Cancer. 2017;123(3):476-484.

32. O'Connor JM, Kircher SM, de Souza JA. Financial toxicity in cancer care. J Comm Supp Oncol. 2016;14(3):101-106.

33. Casilla-Lennon MM, Choi SK, Deal AM, et al. Financial toxicity in bladder cancer patients - reasons for delay in care and effect on quality of life. J Urol. 2018;199(5):1166-1173.

34. Huntington SF, Weiss BM, Vogl DT, et al. Financial toxicity in insured patients with multiple myeloma: a cross-sectional pilot study. Lancet Haematol. 2015;2(10):e408-e416.

35. European Medicines Agency. Biosimilars in the EU: information guide for healthcare professionals. 2017; http://www.ema.europa.eu/ docs/en_GB/document_library/Leaflet/2017/05/WC500226648.pdf. Accessed May 24, 2017.

36. Simoens S. Biosimilar medicines and cost-effectiveness. Clinicoecon Outcomes Res. 2011;3:29-36.

37. IMS Institute for Healthcare Informatics. Delivering on the potential of biosimilar medicines: the role of functioning competitive markets. [updated March 2016]; http://www.imshealth.com/files/web/ IMSH\%20Institute/Healthcare\%20Briefs/Documents/IMS_Institute_Biosimilar_Brief_March_2016.pdf. Accessed June 14, 2017.

38. European Medicines Agency [webpage on the Internet]. European public assessment reports (EPAR) for human medicines: biosimilars. 2017; http://www.ema.europa.eu/ema/index.jsp?curl=pages/medicines/landing/epar_search.jsp\&mid=WC0b01ac058001d125 http:// www.ema.europa.eu/ema/index.jsp?mid=WC0b01ac058001d125\&s earchType $=$ name $\&$ taxonomyPath $=$ Diseases $\&$ searchGenericType $=\mathrm{g}$ enerics\&keyword=Enter+keywords\&alreadyLoaded=true\&curl=pa ges\%2Fmedicines\%2Flanding\%2Fepar_search.jsp\&status=Authoris ed\&status $=$ Withdrawn\&status $=$ Suspended \&status $=$ Refused \&current Category $=$ Cancer $\&$ treeNumber $=\&$ searchTa $=\&$ pageNo $=2$. Accessed August 18, 2017.

39. Gascon P, Tesch H, Verpoort K, et al. Clinical experience with Zarzio ${ }^{\circledR}$ in Europe: what have we learned? Supp Care Cancer. 2013;21(10):2925-2932.

40. Araujo FC, Goncalves J, Fonseca JE. Pharmacoeconomics of biosimilars: what is there to gain from them? Curr Rheumatol Rep. 2016;18(8):50.

41. European Medicines Agency. Applications for new human medicines under evaluation by the Committee for Medicinal Products for Human Use: August 2017; EMA/506776/2017. http://www.ema.europa.eu/ docs/en_GB/document_library/Report/2017/08/WC500233092.pdf. Accessed August 18, 2017.

42. Truven Health Analytics. Biosimilar Market Access, A FirstWord Perspectives Report. Truven Health Analytics, an IBM Company Ann Arbor, MI, USA; October 2016.

43. Mestre-Ferrandiz J, Towse A, Berdud M. Biosimilars: how can payers get long-term savings? Pharmacoeconomics. 2016;34(6):609-616.

44. Informatics IIfH. The Impact of Biosimilar Competition in Europe. Parsippany, NJ; May 2017.

45. Abraham I, Han L, Sun D, MacDonald K, Aapro M. Cost savings from anemia management with biosimilar epoetin alfa and increased access to targeted antineoplastic treatment: a simulation for the EU G5 countries. Future Oncol. 2014;10(9):1599-1609.

46. Manolis CH, Rajasenan K, Harwin W, McClelland S, Lopes M, Farnum C. Biosimilars: opportunities to promote optimization through payer and provider collaboration. J Manag Care Spec Pharm. 2016;22(Suppl 9):S3-S9.

47. Farhat F, Othman A, el Karak F, Kattan J. Review and results of a survey about biosimilars prescription and challenges in the Middle East and North Africa region. Springerplus. 2016;5(1):2113.

48. Bennett CL, Chen B, Hermanson T, et al. Regulatory and clinical considerations for biosimilar oncology drugs. Lancet Oncol. 2014;15(13):E594-E605.
49. U.S. Government. Biologics Price Competition and Innovation Act, sections 7001-7003; Public law no. 111-148. 2009; https://www.fda. gov/downloads/Drugs/GuidanceComplianceRegulatoryInformation/ UCM216146.pdf. Accessed May 18, 2017.

50. Office USCB. S. 1695 Biologics Price Competition and Innovation Act of 2007. 2008. https://www.cbo.gov/publication/41712. Accessed June 28, 2017.

51. Christl L, Deisseroth A [webpage on the Internet]. Development and approval of biosimilar products. 2015; http://www.ascopost.com/issues/ march-25-2015/development-and-approval-of-biosimilar-products/. Accessed May 18, 2017.

52. Christl LA, Woodcock J, Kozlowski S. Biosimilars: the US regulatory framework. Annu Rev Med. 2017;68:243-254.

53. Novartis AG [news release] [webpage on the Internet]. Sandoz launches Zarxio ${ }^{\mathrm{TM}}$ (filgrastim-sndz), the first biosimilar in the United States. 2015; https://www.novartis.com/news/media-releases/sandozlaunches-zarxiotm-filgrastim-sndz-first-biosimilar-united-states. Accessed June 14, 2017.

54. Raedler LA. Zarxio (filgrastim-sndz): first biosimilar approved in the United States. Am Health Drug Benefits. 2016;9(Spec Feature): $150-154$.

55. McBride A, Campbell K, Bikkina M, MacDonald K, Abraham I, Balu S. Cost-efficiency analyses for the US of biosimilar filgrastim-sndz, reference filgrastim, pegfilgrastim, and pegfilgrastim with on-body injector in the prophylaxis of chemotherapy-induced (febrile) neutropenia. J Med Econ. 2017;20(10):1083-1093.

56. McBride A, Balu S, Campbell K, Bikkina M, MacDonald K, Abraham I. Expanded access to cancer treatments from conversion to neutropenia prophylaxis with biosimilar filgrastim-sndz. Future Oncol. 2017;13(25):2285-2295.

57. RED BOOK Online ${ }^{\circledR}$ pricing: Filgrastim, Filgrastim-sndz, Tbofilgrastim [webpage on the Internet]. 2017 Truven Health Analytics, an IBM Company; 2017. https://truvenhealth.com/products/micromedex/ product-suites/clinical-knowledge/red-book. Accessed May 24, 2017.

58. Centers for Medicare \& Medicaid Services [webpage on the Internet]. 2017 ASP Drug Pricing Files, July 2017. https://www.cms.gov/Medicare/Medicare-Fee-for-Service-Part-B-Drugs/McrPartBDrugAvgSale sPrice/2017ASPFiles.html. Accessed August 23, 2017.

59. Jacobs I, Ewesuedo R, Lula S, Zacharchuk C. Biosimilars for the treatment of cancer: a systematic review of published evidence. BioDrugs. 2017;31(1):1-36.

60. Rugo HS, Linton KM, Cervi P, Rosenberg JA, Jacobs I [webpage on the Internet]. A clinician's guide to biosimilars in oncology. Cancer Treat Rev. 2016;46:73-79.

61. Generics and Biosimilars Initiative (GaBI). Biologicals patent expiries. 2015; http://www.gabionline.net/Biosimilars/General/Biologicalspatent-expiries. Accessed May 19, 2017.

62. Business Wire [news release] [webpage on the Internet]. FDA Advisory Committee recommends approval of Pfizer's proposed biosimilar to Epogen/Procrit across all indications. 2017; https://www.biosimilardevelopment.com/doc/fda-advisory-committee-recommends-approvalof-pfizer-s-proposed-biosimilar-0001. Accessed June 26, 2017.

63. US Food and Drug Administration. Epoetin Hospira: FDA Advisory Committee Briefing Document. 2017; https://www.fda.gov/downloads/ AdvisoryCommittees/CommitteesMeetingMaterials/Drugs/OncologicDrugsAdvisoryCommittee/UCM559968.pdf. Accessed August 21, 2017.

64. Generics and Biosimilars Initiative (GaBI) [webpage on the Internet]. Apotex petitions FDA over Neulasta biosimilars 2017; http://www. gabionline.net/Guidelines/Apotex-petitions-FDA-over-Neulastabiosimilars. Accessed June 28, 2017.

65. Mylan [news release] [webpage on the Internet]. US FDA Accepts Biologics License Application (BLA) for Mylan and Biocon's Proposed Biosimilar Pegfilgrastim for Review. 2017; http://newsroom. mylan.com/2017-02-16-U-S-FDA-Accepts-Biologics-LicenseApplication-BLA-for-Mylan-and-Biocons-Proposed-BiosimilarPegfilgrastim-for-Review. Accessed June 28, 2017. 
66. Generics and Biosimilars Initiative (GaBI) [webpage on the Internet]. FDA accepts application for pegfilgrastim biosimilar. 2015; http:// www.gabionline.net/Biosimilars/News/FDA-accepts-application-forpegfilgrastim-biosimilar. Accessed June 28, 2017.

67. Adello Biologics [webpage on the Internet]. FDA Accepts Adello's Biosimilar Biologics License Application (BLA) for a Proposed Filgrastim Biosimilar. 2017; http://adellobio.com/news/2017/fdaaccepts-adellos-biosimilar-biologics-license-application-bla-for-aproposed-filgrastim-biosimilar. Accessed November 20, 2017.

68. Celltrion and Teva Announce U.S. FDA Acceptance of Biologics License Application for Proposed Biosimilar to Herceptin ${ }^{\circledR}$ (trastuzumab) [press release]. http://phx.corporate-ir.net/phoenix. zhtml?c=251945\&p=irol-newsArticle\&ID=2290123. July 31, 2017.

69. U.S. FDA accepts Biologics License Application (BLA) for Mylan and Biocon's Proposed Biosimilar Trastuzumab [press release]. http:// investor.mylan.com/news-releases/news-release-details/us-fda-acceptsbiologics-license-application-bla-mylan-and. January 12, 2017.

70. Amgen and Allergan Submit Biosimilar Biologics License Application for ABP 980 to US Food And Drug Administration [press release]. https://www.prnewswire.com/news-releases/amgen-and-allergansubmit-biosimilar-biologics-license-application-for-abp-980-to-usfood-and-drug-administration-300496238.html. July 31, 2017.

71. Sorenson C, Lavezzari G, Daniel G, et al. Advancing value assessment in the United States: a multistakeholder perspective. Value Health. 2017;20(2):299-307.

72. Schnipper LE, Davidson NE, Wollins DS, et al. Updating the American Society of Clinical Oncology value framework: revisions and reflections in response to comments received. J Clin Oncol. 2016;34(24):2925-2934.

73. Memorial Sloan Kettering Cancer Center [webpage on the Internet] DrugAbacus methods. 2017; http://drugpricinglab.org/tools/louisianabudget-allocator/methods/. Accessed May 18, 2017.

74. National Comprehensive Cancer Network [webpage on the Internet]. NCCN clinical practice guidelines in oncology (NCCN Guideliness) with NCCN Evidence Blocks ${ }^{\mathrm{TM}}$. 2017; https://www.nccn.org/evidenceblocks/. Accessed May 18, 2017.

75. Institute for Clinical and Economic Review. ICER value assessment framework. 2017; https://icer-review.org/methodology/icers-methods/ icer-value-assessment-framework/. Accessed May 18, 2017.

76. SMC. Re-submission: olaparib, 50mg, hard capsules (Lynparza $\left.{ }^{\circledR}\right)$ SMC No. (1047/15) AstraZeneca UK. UK: Scottish Medicies Consortium; 2016, SMC No. 1047/15.

77. Clough JD, Kamal AH. Oncology care model: short- and long-term considerations in the context of broader payment reform. J Oncol Pract. 2015;11(4):319-321.

78. Centers for Medicare \& Medicaid Services (CMS) [webpage on the Internet]. The Quality Payment Program. 2016 [news release]; https:// www.cms.gov/Newsroom/MediaReleaseDatabase/Fact-sheets/2016Fact-sheets-items/2016-10-25.html. Accessed August 21, 2017.

79. Centers for Medicare \& Medicaid Services (CMS), Department of Health \& Human Services. The Quality Payment Program Overview Fact Sheet. 2016; https://qpp.cms.gov/docs/Quality_Payment_Program_Overview_Fact_Sheet.pdf. Accessed August 22, 2017.

80. Centers for Medicare \& Medicaid Services (CMS), Department of Health \& Human Services [webpage on the Internet]. Quality Payment Program. 2016; https://qpp.cms.gov/. Accessed August 21, 2017.

81. Centers for Medicare \& Medicaid Services (CMS), Department of Health \& Human Services. The Quality Payment Program [slide presentation]. 2016; https://www.cms.gov/Medicare/QualityInitiatives-Patient-Assessment-Instruments/Value-Based-Programs/ MACRA-MIPS-and-APMs/Quality-Payment-Program-Long-VersionExecutive-Deck.pdf. Accessed August 21, 2017.

82. Dong LF, Pelizzari PM [webpage on the Internet]. Advanced APMs and Qualifying APM Participant Status. 2016; http://www.milliman. com/insight/2016/Advanced-APMs-and-Qualifying-APM-Participantstatus/. Accessed August 31, 2017.
83. Centers for Medicare \& Medicaid Services. U.S. Department of Justice. Medicare Shared Savings Program ACO: Preparing to Apply for the 2018 Program Year [slide presentation]. 2017; https://www.cms.gov/ Outreach-and-Education/Outreach/NPC/Downloads/2017-04-06-SSPPresentation.pdf. Accessed August 31, 2017.

84. U.S. Centers for Medicare \& Medicaid Services (CMS) [webpage on the Internet]. Oncology Care Model. 2017; https://innovation.cms. gov/initiatives/oncology-care/. Accessed August 18, 2017.

85. Centers for Medicare \& Medicaid Services (CMS) [webpage on the Internet]. Fact Sheets: Oncology Care Model. 2016; https://www.cms. gov/Newsroom/MediaReleaseDatabase/Fact-sheets/2016-Fact-sheetsitems/2016-06-29.html. Accessed May 19, 2017.

86. (CMS) USCfMMS. Oncology Care Model: Key Drivers \& Change Package. https://innovation.cms.gov/Files/x/ocm-keydrivers-changepkg.pdf. September 6, 2017. Accessed September 28, 2017.

87. Chan A, McGregor S, Liang WB. Utilisation of primary and secondary G-CSF prophylaxis enables maintenance of optimal dose delivery of standard adjuvant chemotherapy for early breast cancer: an analysis of 1655 patients. Breast. 2014;23(5):676-682.

88. Aapro M, Cornes P, Abraham I. Comparative cost-efficiency across the European G5 countries of various regimens of filgrastim, biosimilar filgrastim, and pegfilgrastim to reduce the incidence of chemotherapyinduced febrile neutropenia. J Oncol Pharm Pract. 2012;18(2): 171-179.

89. Sun D, Andayani TM, Altyar A, MacDonald K, Abraham I. Potential cost savings from chemotherapy-induced febrile neutropenia with biosimilar filgrastim and expanded access to targeted antineoplastic treatment across the European Union G5 countries: a simulation study. Clin Ther. 2015;37(4):842-857.

90. Aapro M, Cornes P, Sun D, Abraham I. Comparative cost efficiency across the European G5 countries of originators and a biosimilar erythropoiesis-stimulating agent to manage chemotherapy-induced anemia in patients with cancer. Ther Adv Med Oncol. 2012;4(3): 95-105.

91. Gulacsi L, Brodszky V, Baji P, Rencz F, Pentek M. The rituximab biosimilar CT-P10 in rheumatology and cancer: a budget impact analysis in 28 European countries. Adv Ther. 2017;34(5):1128-1144.

92. Cesarec A, Likić R. Budget impact analysis of biosimilar trastuzumab for the treatment of breast cancer in Croatia. Appl Health Econ Health Policy. 2016;15(2):277-286.

93. Farfan-Portet MI, Gerkens S, Lepage-Nefkens I, Vinck I, Hulstaert F. Are biosimilars the next tool to guarantee cost-containment for pharmaceutical expenditures? Eur J Health Econ. 2014;15(3): 223-228

94. Boccia R, Jacobs I, Popovian R, de Lima Lopes G, Jr. Can biosimilars help achieve the goals of US health care reform? Cancer Manag Res. 2017;9:197-205.

95. Kyodo [webpage on the Internet]. Generic Drugs to be Priced at 10\% Less From April. The Japan Times Online, 2015; https://www. japantimes.co.jp/news/2015/12/02/national/science-health/genericdrugs-to-be-priced-at-10-less-from-april/\#.Wal0irKGO1t. Accessed September 8, 2017.

96. Momin Z, Wijaya C, Bernardo P [webpage on the Internet]. Will Asia Go Big in Biosimilars Adoption and Manufacturing? Biosimilar Development 2017; May 18, 2017: https://www.biosimilardevelopment.com/doc/will-asia-go-big-in-biosimilars-adoption-and-manufacturing-0001. Accessed September 8, 2017.

97. Japan Announces Proposed Plan to Reduce Biosimilar and Generic Drug Prices [webpage on the Internet]. Big Molecule Watch 2016; http://www.bigmoleculewatch.com/2016/02/03/japan-announces-proposed-plan-to-reduce-biosimilar-and-generic-drug-prices/. Accessed September 8, 2017.

98. Mulcahy AW, Predmore Z, Mattke S. The cost savings potential of biosimilar drugs in the United States [updated 2014]; https:// www.rand.org/content/dam/rand/pubs/perspectives/PE100/PE127 RAND_PE127.pdf. Accessed June 14, 2017. 
99. Tabernero J, Vyas M, Giuliani R, et al. Biosimilars: a position paper of the European Society for Medical Oncology, with particular reference to oncology prescribers. ESMO Open. 2017;1(6)e 000142.

100. Cohen H, Beydoun D, Chien D, et al. Awareness, knowledge, and perceptions of biosimilars among specialty physicians. Adv Ther. 2017;33(12):2160-2172.

101. Felix AE, Gupta A, Cohen JP, Riggs K. Barriers to market uptake of biosimilars in the US. GaBI J. 2014;3(3):108-115.
102. Market Wired [webpage on the Internet]. Nearly half of US physicians say they will prescribe more biosimilars, according to new data from InCrowd [news release]. 2016; http://www.marketwired.com/ press-release/nearly-half-us-physicians-say-they-will-prescribe-morebiosimilars-according-new-data-2102567.htm. Accessed June 14, 2017.

103. Micklus A. Hot Topic: Biosimilars Market Access in the US. Datamonitor Healthcare, Informa UK Limited, London, UK; 2017.

\section{Publish your work in this journal}

Cancer Management and Research is an international, peer-reviewed open access journal focusing on cancer research and the optimal use of preventative and integrated treatment interventions to achieve improved outcomes, enhanced survival and quality of life for the cancer patient. The manuscript management system is completely online and includes a very quick and fair peer-review system, which is all easy to use. Visit http://www.dovepress.com/testimonials.php to read real quotes from published authors. 